\title{
Changes in Permafrost Distribution Produced by a Migrating River Meander in the Northern Yukon, Canada.
}

\author{
C. B. CRAMPTON
}

\begin{abstract}
Drill hole data from the Eagle River crossing by the Dempster Highway near the Arctic Circle have been interpreted on the basis of point bars formed by a migrating meander loop and dated by tree core ring counts. In the wake of the migrating meander loop, two waves of changes in the state of permafrost have penetrated downwards into the ground, associated with a downward migrating and thickening interpermafrost talik layer containing water under pressure.
\end{abstract}

RESUME. Les renseignements de puits dans I "Eagle River," au passage de la grand'route de Dempster, près du cercle arctiques s'interpretent comme des barres sableuses fluviales, formées par la deplacement d'une boucle de meandre; on les a datées en comptant les anneaux de croissance d'un tronc d'arbre. Au debut de la migration du meandre, il y a eu deux vagues d'approfondissement du permafrost dans le sol, associés avec la migration vers le bas et l'épaississement d'une lentille interne au permafrost, contenant de l'eau sous pression.

Traduit par Alain de Vendegies, Aquitaine Company of Canada Ltd.

\section{INTRODUCTION}

As part of the Dempster Highway, in the northern Yukon the Eagle River was bridged during the winter of 1976 and 1977 by the Canadian Military Engineers. Public Works Canada carried out the initial investigations, including drilling during 1973 and 1974. Five major holes, about $29-34 \mathrm{~m}$

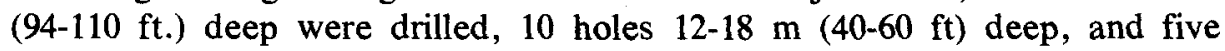
shallow holes $5-9 \mathrm{~m}(15-30 \mathrm{ft})$. The test hole data and levelling prior to construction of the bridge have been plotted (Fig. 1). The migration of a meander loop across the study-area had allowed thawing of the permafrost in the substrate. An interpretation of the data yielded information on the rate of descent of new permafrost into the ground.

\section{PHYSIOGRAPHY}

The site is $16 \mathrm{~km}(10 \mathrm{mi})$ south of the Arctic Circle (latitude $662 / 3^{\circ} \mathrm{N}$ ), in the transition from the Discontinuous to the Continuous Permafrost Zones (Brown, 1967). Alluvium of layered gravels, sands and silts overlies a till of sandy clays and silts. The profile across the river sections a meander loop which is migrating northwards. This meander loop shows in cross-section the pool of a pool and riffle sequence characteristic of a meandering river 


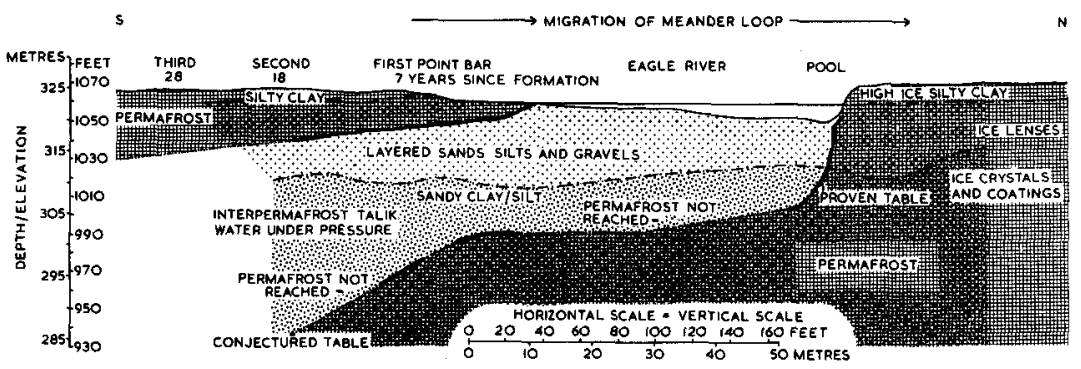

FIG. 1. Distribution of permafrost and substrate below and on either side of the Eagle River.

(Kolenkow, 1974), the high-velocity current being thrown against the outermost bank of the meander as it turns, eroding a bluff into the alluvial plain (Fig. 1). The slip-off slope occurs against the southern, innermost bank of the meander. As the river meander has migrated northwards, it has left a succession of point bars in the form of scrolls, identified as first nearest the inside of the meander loop, and second and third progressively further away from the present river course. The forest cover established on these point bars is mostly white spruce and birch.

\section{PROCEDURE}

Data from the drill holes have been interpreted to construct a vertical profile through the river and substrate, showing the distribution of permafrost below the river and point bars. Trees on each point bar were cored to allow the determination of their age, and the average age was then assumed to be the elapsed time since the point bar's formation by the northward migrating Eagle River (fig. 1).

\section{RESULTS}

Where there is permafrost, the greatest ice content is near the land surface, the ice occurring in numerous lenses. At greater depths the ice is distributed through the substrate as some lenses, scattered crystals and coatings around grains. North of the meander loop, deep borings failed to locate the base of the permafrost, and so it can be assumed that permafrost extends to greater than $34 \mathrm{~m}(110 \mathrm{ft})$. Below the present course of the river, on the north side the

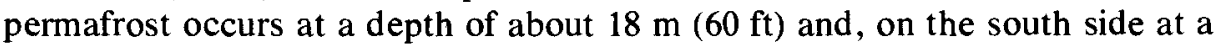
depth of about $21 \mathrm{~m} \mathrm{(70} \mathrm{ft).} \mathrm{These} \mathrm{depths} \mathrm{are} \mathrm{based} \mathrm{partly} \mathrm{on} \mathrm{holes} \mathrm{drilled}$ through the present permafrost table, and partly on holes that failed to reach the permafrost table, indicating its presence at greater depths than the drill hole. Below the point bars south of the river the permafrost table plunges to about $40 \mathrm{~m}$ (130 ft).

Commencing at the southern edge of the meander loop, permafrost is present near the ground surface, and it increases in thickness southwards, under successively older point bars dated by tree core ring counts, to a depth of $11 \mathrm{~m}(25 \mathrm{ft})$ below the 28-year-old third point bar at a distance of $60 \mathrm{~m} \mathrm{(200}$ 
ft) from the inside of the meander loop. The interface of this uppermost permafrost-talik boundary is less steep than the interface of the lowermost talik-permafrost boundary (Fig. 1), the two interfaces defining the thickness of the interpermafrost talik or unfrozen substrate from about $23 \mathrm{~m}(75 \mathrm{ft}$ ) below the first point bar, to about $38 \mathrm{~m}(125 \mathrm{ft})$ below the second point bar. This talik is saturated with water which drilling revealed as under pressure.

\section{INTERPRETATION}

On the basis of the point bar ages determined by tree coring, the river has been migrating northwards at the rate of $2.2 \mathrm{~m}(7 \mathrm{ft})$ per year. The erosive power of a river is greatest during the spring flood flow and, presumably, most of this erosion of the outermost bank of the meander loop occurs during spring. The 1972 July summer depth of the pool was about $3 \mathrm{~m}(9 \mathrm{ft})$. During spring of 1971 the depth of the pool was $5.5 \mathrm{~m}$ (18 ft), and the extreme flood depth of the pool has been estimated at about $8 \mathrm{~m}(25 \mathrm{ft})$.

On the north side of the meander loop earlier floods are presumed to have been responsible for the deposition of about $3 \mathrm{~m} \mathrm{(10} \mathrm{ft)} \mathrm{of} \mathrm{silty} \mathrm{clay} \mathrm{over} \mathrm{the}$ alluvial gravels, sands and silts. On the south side of the meander loop, from about 7 years and later, there appears to have been an accumulation of silty clay over the alluvium, to a depth of about $2 \mathrm{~m}(7 \mathrm{ft})$, presumably by recent (during the last 20 years) flooding.

As the river has migrated northwards, the water surface has allowed a greater transfer of summer warmth into the substrate below the river than below land, causing the thawing of permafrost, a phenomenon widely reported in the north, to depths between $18 \mathrm{~m}(60 \mathrm{ft})$ and $21 \mathrm{~m}(70 \mathrm{ft})$. Also as the river has migrated northwards, permafrost has developed in the point bars left behind by this migration, thickening at the rate of about $0.37 \mathrm{~m}(1.2 \mathrm{ft})$ per year, evaluated on the basis of the tree corings and age estimates for the point bars. Below the point bars and under the interpermafrost talik, the permafrost table has thawed downwards at the rate of about $0.95 \mathrm{~m}(3 \mathrm{ft})$ per year, more than twice the rate of descent of the under-surface of the permafrost above the interpermafrost talik. Thus, the interpermafrost talik has been increasing in thickness at the rate of about $0.55 \mathrm{~m}(18 \mathrm{ft})$ per year.

The two layers of permafrost define between them an aquifer in the interpermafrost talik of principally gravels and sands over sandy silts and clays, the summer river bed being an ample recharge area. High pore pressures recorded in this talik can thaw permafrost (Embleton and King, 1975), possibly contributing to the faster rate of descent of the permafrost table below the talik compared with the lower interface of the accumulating permafrost at the ground surface.

\section{SOME PRACTICAL CONSIDERATIONS}

To protect the bridge abutments against floods, each pile cap has been enveloped with piling cribs filled with rock, and the banks have been armoured with about 1016 metric tons (1000 tons) of gabions, $61 \mathrm{~m}(200 \mathrm{ft})$ 
upstream and $15 \mathrm{~m}(50 \mathrm{ft})$ downstream of the bridge. This armouring should stop further migration of the meander.

15 steel $\mathrm{H}$-piles support the bridge at each abutment. At the north abutment holes were drilled into the permafrost and the piles driven to refusal at a depth

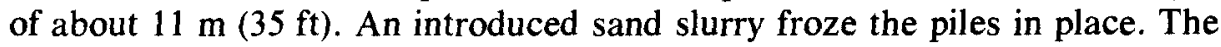
bridge bearings were constructed on the assumption that the south abutment was the more stable. At this south abutment between the first and second point bars, the piles were driven to refusal at a greater depth than on the north side to about $30 \mathrm{~m}(100 \mathrm{ft})$, which would have brought them to a position of rest approximately on the present permafrost table below the interpermafrost talik. This permafrost table is thawing downwards, away from the base of the piles. However, the surface permafrost is freezing downwards around the piles, albeit more slowly than the lower permafrost table is thawing. With the passage of time the stability of the southern abutment is improving. Meanwhile the much greater depth of the piles on the southern side compared with the northern side should ensure adequate stability.

\section{CONCLUSIONS}

The migration of a meander loop of the Eagle River in northern Yukon across an area of land with permafrost has caused profound changes in the distribution of permafrost. As the outermost bank of the meander loop has eroded into and migrated across the coarse-textured flood plain, the summer's warmth has been allowed into the ground, to thaw the permafrost. Point bars have formed behind the migrating meander loop, and spring floods have mantled these bars with silty clay. Permafrost has developed in the bar deposits, and is thickening annually. Water in the interpermafrost talik separating this newly forming permafrost from the lower, thawing permafrost table is under pressure, which may be responsible for the accelerated rate of thawing shown by this table as it descends at twice the rate of the overlying freezing interface. Thus, with the passage of time, in the wake of the migrating meander loop, two waves of changes in the state of permafrost have penetrated downwards into the ground, characterized by a downward migrating and thickening interpermafrost talik layer. Presumably, these changes will continue at a decreasing rate until the equilibrium depth of permafrost for the area is achieved.

\section{REFERENCES}

BRown. R. J. E. 1967. Permafrost in Canada, Geological Survey, Map 1246A, Department of Energy, Mines and Resources.

embletON. C. and King. C. A. M. 1975. Periglacial Geomorphology. London, Edward Arnold (Publishers) Ltd.

Kolenkow, R. J. 1974. Physical Geography Today. Del Mar California, CRM Books. 